\title{
Cem números de ADE-Teatro
}

\author{
Luiz Francisco Rebello
}

\author{
ADE - Teatro: Revista trimestral de la Asociación de Directores de Escena de España, \\ n. ${ }^{\circ}$ 100, Abril - Junho 2004.
}

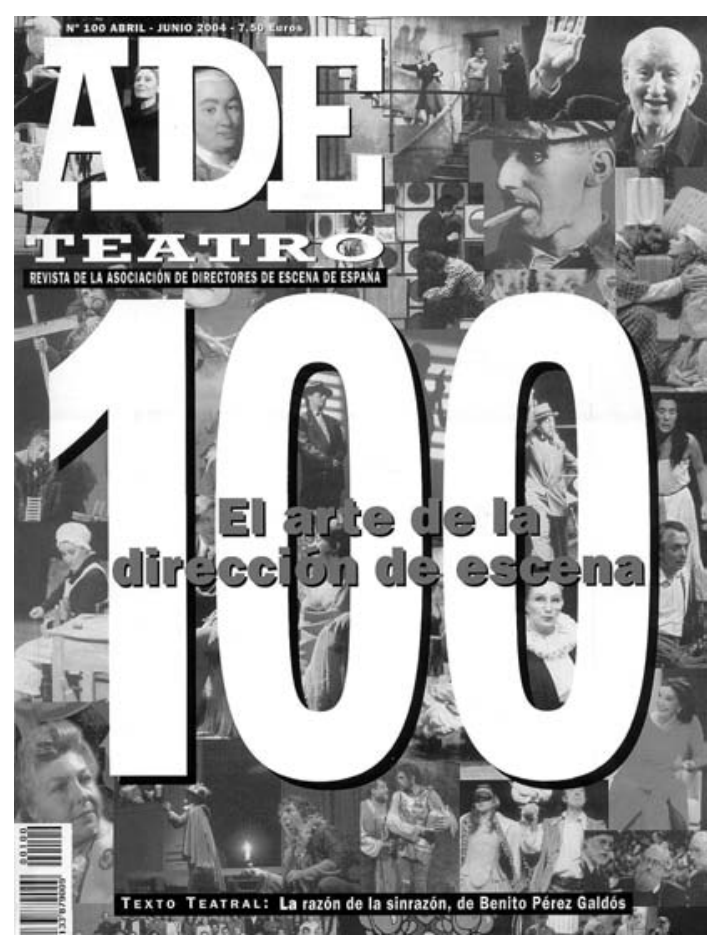

Em 1982 os encenadores espanhóis fundaram uma associação - a ADE (Associación de los Directores de Escena) -, que três anos depois iniciava a publicação de um boletim, de periodicidade irregular. Mais cinco anos haviam de passar $e_{\text {, }}$ a partir do n. 16 , o boletim assumia-se como revista, sob o impulso dinâmico e dinamizador do Secretário da Associação, Juan António Hormigón, catedrático de teatro, com a denominação $A D E$ - Teatro e periodicidade trimestral. 0 último número publicado, referente aos meses de Abril a Junho de 2004, é o n.o 100.

No panorama das publicações periódicas dedicadas à arte dramática (seria doloroso comparar a penúria doméstica que noutros paises nesta área se verifica...), a $A D E$-Teatro ocupa um lugar que sem exagero se pode considerar ímpar. Tendo como objectivo - nas palavras do seu director, Hormigón "compaginar a informação e análise sobre questões da actualidade cénica com estudos de historiografia, teoria e técnica de teatro", e incluindo em cada entrega pelo menos um texto dramático, a revista tem vindo a cumprir exemplarmente esse programa. Mas, como também adverte Hormigón, "não é possivel falar de teatro de forma endogâmica, à margem das contradições sociais, do devir histórico, dos sofrimentos e esperanças dos homens e dos povos". Sempre o teatro existe na e para a cidade, e essa perspectiva acompanha, enquadra e esclarece todo o material publicado.

Assim é que nas suas páginas se têm discutido temas da maior acuidade, entre os quais - para citar apenas alguns - 0 teatro como serviço público, os direitos do encenador, o exercício da profissão do encenador nas suas relações com o dramaturgo e o público, a função da crítica teatral, o mercado do espectáculo cénico. E não só a esses temas, através de debates teóricos, de entrevistas, de estudos críticos, por vezes com recurso a testemunhos históricos, se têm aberto as colunas da revista, como nelas se têm albergado dossiês relativos a grandes personalidades do teatro contemporâneo: dramaturgos como Brecht, encenadores como Strehler, ao teatro de uma época (a guerra civil e o exílio, por exemplo), uma região, um pais (e ao teatro português actual, por exemplo, também foi dedicado o número duplo relativo ao $2 .{ }^{\circ}$ semestre de 1997). $\mathrm{E}_{1}$ entre os textos dados a conhecer, figuram obras de modernos autores espanhóis, de Heiner Müller, Alexander Vampilov, Michel Vinaver, Sarah Kane, Eduardo De Filippo - e O fim, ou tende misericórdia de nós, de Jorge Silva Melo.

Não se esgota, porém, nesta excelente revista a actividade da $A D E$, que paralelamente edita três colecções: uma dedicada à teoria e prática do teatro, onde se incluem volumes monográficos sobre Meyerhold, Copeau, Goldoni e o texto integral da Dramaturgia de Hamburgo, de Lessing; outro é a literatura dramática iberoamericana; uma terceira sobre literatura dramática universal, cujo último volume publicado é o Frei Luís de Sousa, de Garrett, traduzido por lolanda Ogando, com o apoio, laboriosamente conseguido, do Instituto Camões.

0 número centenário da revista, nas suas mais de 300 páginas, tem como tema central a encenação e o encenador, analisados numa pluralidade de ângulos: histórico, profissional, deontológico, teórico, prático e jurídico. Apoiam esta análise textos de Antoine, Appia, Gordon Craig, Copeau, Max Reinhart, Meyerhold, Piscator, Peter Stein, Bob Wilson, Boal e outros mais, introduzidos por um texto de grande rigor e densidade de informação assinado por Pablo Iglesias Simón. E recolhemse depoimentos de várias personalidades do mundo teatral, de Espanha e não só, alusivos à efeméride cuja importância e significado sublinham e exaltam. A estes materiais, publicados em suporte papel, acrescenta ainda a revista um CD com indice de sócios, cronologia da ADE (de 1982 a 2003), catálogo das publicações da Associação, índice da revista (do 1. ${ }^{\circ}$ ao $99^{\circ}$ número) e os prémios $A D E$.

Sinais de cena associa-se, no seu primeiro número, à homenagem assim prestada a ADE - Teatro pelo seu centésimo número e ao seu director, que tem sido um activo e entusiástico defensor da aproximação luso-espanhola na área do teatro. 